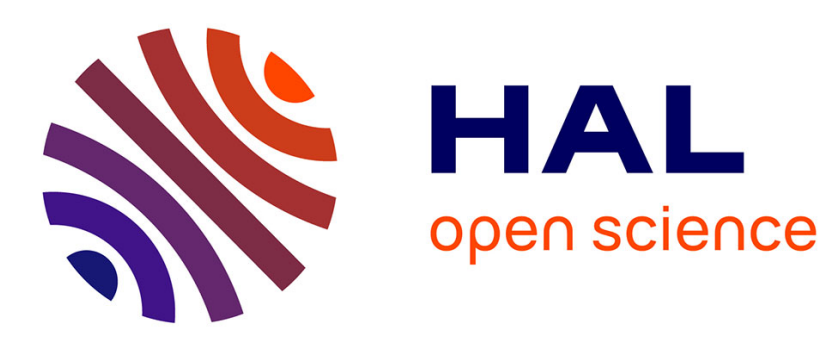

\title{
Ancient juniper trees growing on cliffs: toward a long Mediterranean tree-ring chronology
}

Coralie Mathaux, Jean-Paul Mandin, Christine Oberlin, Jean-Louis Édouard, Thierry Gauquelin, Frédéric Guibal

\section{- To cite this version:}

Coralie Mathaux, Jean-Paul Mandin, Christine Oberlin, Jean-Louis Édouard, Thierry Gauquelin, et al.. Ancient juniper trees growing on cliffs: toward a long Mediterranean tree-ring chronology. Dendrochronologia, 2016, 37, pp.79-88. 10.1016/j.dendro.2015.12.005 . hal-01444067

\author{
HAL Id: hal-01444067 \\ https://hal.science/hal-01444067
}

Submitted on 15 Feb 2022

HAL is a multi-disciplinary open access archive for the deposit and dissemination of scientific research documents, whether they are published or not. The documents may come from teaching and research institutions in France or abroad, or from public or private research centers.
L'archive ouverte pluridisciplinaire HAL, est destinée au dépôt et à la diffusion de documents scientifiques de niveau recherche, publiés ou non, émanant des établissements d'enseignement et de recherche français ou étrangers, des laboratoires publics ou privés. 


\title{
Ancient juniper trees growing on cliffs: toward a long Mediterranean tree-ring chronology
}

\author{
Coralie Mathaux ${ }^{\mathrm{a}, *}$, Jean-Paul Mandin ${ }^{\mathrm{b}}$, Christine Oberlin ${ }^{\mathrm{c}}$, Jean-Louis Edouard ${ }^{\mathrm{d}}$, \\ Thierry Gauquelin ${ }^{\mathrm{a}}$, Frédéric Guibal ${ }^{\mathrm{a}}$ \\ a Aix Marseille Université - IMBE (Institut Méditerranéen de Biodiversité et d'Ecologie Marine et Continentale) - UMR 7263 CNRS AMU IRD UAPV, 3 Place \\ Victor Hugo, 13331 Marseille Cedex 03, France \\ b Société Botanique de l'Ardèche, Réserve Naturelle Nationale des Gorges de l'Ardèche, 2649 Route de St. Paulet, 30760 St. Julien-de-Peyrolas, France \\ ' Centre de Datation par le Radiocarbone-UMR 5138 CNRS Université Claude Bernard Lyon I, 40 Boulevard Niels Bohr, 69622 Villeurbanne Cedex, France \\ d Aix Marseille Université, CNRS, Ministère de la Culture et de la Communication, CCJ UMR 7299, 13094 Aix-en-Provence, France
}

\section{A R T I C L E I N F O}

Article history:

Received 6 July 2015

Received in revised form 25 October 2015

Accepted 3 December 2015

Available online 18 December 2015

Keywords:

Radiocarbon

Wiggle-matching

Extreme longevity

Cliff

Juniperus phoeniced

Stunted trees

\begin{abstract}
A B S T R A C T
Juniperus phoenicea is a tree that can grow on vertical cliff faces in dry and warm Mediterranean climate conditions. These trees are adapted to extreme growing conditions where the main constraints are verticality, compact hard limestone, and low water supply. They respond to these constraints via various specific features and high longevity. The objective of this study is to confirm whether or not their tree-rings are annual in order to specify growth strategies and accurately date these trees. Trunk morphology, anatomical wood anomalies and radial growth were analyzed on 53 trees in the Ardèche canyon. Crossdating of the ring widths using traditional dendrochronological techniques was unsuccessful, so radiocarbon dating of tree pith was used to assess tree age, and wiggle-match dating was used to test for differences between number of rings counted and radiocarbon dates. Radiocarbon dates span the period 2520-685 BP. Minimal difference between radiocarbon dates and ring counts was apparently small-missing rings occur, but not in large numbers. Tree-ring formation is annual and radial growth is low, which creates stunted old trees. Such old living trees are uncommon in the Mediterranean basin especially at low elevation. They can provide long tree-ring chronologies back to $792-524$ cal BC. Results from the radiocarbon dating indicate that accurate annual dating of these rings may be possible by crossdating. J. phoenicea growing on cliffs offer a valuable model to better understand cliff population ecology and the functional responses of trees that can live in harsh environmental conditions.
\end{abstract}

\section{Introduction}

Most forest ecosystems have been impacted by human civilizations on both spatial and temporal scales (Blondel and Aronson, 1999), but work by Larson et al. (1999, 2000) shows that cliffs support ancient, primary or virgin woodland, as cliff face habitats are too inaccessible to support anthropogenic disturbances. Trees that are able to grow on cliff faces have to support high abiotic constraints such as a limited root space, a low water storage capacity, and recurrent rockfalls (Larson et al., 1993; Matthes and Larson, 2006), but in turn they benefit from the absence of logging, fires, grazing, and competition from more aggressive level-ground vegetation. A study of 65 different temperate climate-zone cliffs

\footnotetext{
* Corresponding author.

E-mail address: coralie.mathaux@imbe.fr (C. Mathaux).
}

reported exceptional longevity in some treelike cliff species such as Thuja occidentalis, (Northern USA), Juniperus virginiana (USA), Taxus baccata (United Kingdom), Juniperus phoenicea (Verdon canyon, France), which can reach ages of over 1000 years (Larson et al., 2000). Other studies confirm this site-specific longevity: a 1890year Thuya occidentalis was discovered in the Niagara Escarpment (Southern Ontario, Canada; Larson, 2001) and a 1500-growth-layer J. phoenicea was found in Ardèche canyon (South of France, Mandin, 2005).

J. phoenicea L. (family Cupressaceae) is a treelike shrub or small evergreen tree growing up to twelve meters tall (Farjon, 2005). Its geographic range extends from the Canary Islands and the Atlas mountains in Africa in the West, to Jordan and Saudi Arabia in the East (Dzialuk et al., 2011), where it thrives under Mediterranean climate. It is a heliophilous, xerophilous and thermophilous species (Rameau et al., 2008) of saxicline plant that is found on rocky soils or orthent in the Mediterranean region (Garraud, 2003). Two sub- 
species are identified, $J$. phoenicea subsp. turbinata in populations of the coastal maritime areas and J. phoenicea subsp. phoenicea in all the other populations growing in hinterland landscapes up to $2500 \mathrm{~m}$ asl, such as on the slopes of the Atlas Mountains. It is a drought-tolerant, light-demanding tree characterized by pioneer properties (Quézel and Pesson, 1980; Quézel and Médail, 2003). The Ardèche marks the northern limit of its distribution on the right bank of the Rhône.

In the French Mediterranean region, populations of $J$. phoenicea tree can also grow on vertical and exposed limestone cliffs. These trees are adapted to extreme growing conditions where the main constraints are verticality and compact hard limestone that place strong mechanical stress on roots, which effectively limits both their growth and nutrients and water supply in dry and warm Mediterranean climate conditions. J. phoenicea tree colonizing these very harsh sites respond to these constraints via various specific features, one of which is a deformed gross architecture with slow and often asymmetric growth and a high proportion of stripbark where trunk dieback is caused by partial cambium mortality. Stem or trunk stripping is known to occur in angiosperms and gymnosperms but is most common in the Cupressaceae family (Matthes et al., 2002). It is possible that this significant partial cambial mortality is triggered by hydraulic pathway sectoriality. Sectoriality means that there is no radial sap flow, i.e., each root only supplies the radial part of the crown to which it is connected (Mandin, 2006).

Trees can reach exceptional lifespans (Mandin, 2005). In the Mediterranean region, a major problem in achieving long tree-ring chronologies is the scarcity of long-lived trees which often results of anthropogenic impact (Luterbacher et al., 2012). A further problem is that a majority of the few long-lived trees in the Mediterranean Basin are evergreens that produce anatomical anomalies such as double rings (Cherubini et al., 2003), features that make crossdating very difficult. However, some authors have proposed that tree rings of long-lived Mediterranean evergreens, such as Juniperus sp. and Quercus ilex L. can nevertheless be dated and used for dendrochronological studies (Cherubini et al., 2003; Campelo et al., 2007).

J. phoenicea demonstrates especially remarkable longevity and are abundant in the cliffs of the Ardèche valley. The longevity of these trees in such habitats potentially offers very long tree-ring series, but as with many other Cupressaceae species, there is persistent uncertainty over the annual status of a ring (Lemoine, 1966; Abdoun et al., 2005; Couralet et al., 2005). However, in another evergreen cliff species in Canada, a 1397-year tree-ring chronology has been built, and radial increment was negatively correlated with the previous year's maximum summer temperature (Kelly et al., 1994).

The objectives of this study were to accurately date J. phoenicea growing on cliffs and determine the representativeness of a ring. For this purpose, three techniques are used: cross-dating, radiocarbon dating on the tree pith to determine the age, and wiggle-match dating to test for differences between number of rings counted and radiocarbon dates.

\section{Materials and methods}

\subsection{Field study}

This study was performed on vertical cliffs (altitude range $50-300 \mathrm{~m}$ ) in the protected nature reserve of Ardèche canyon in Southeast France (Fig. 1) and its surroundings. Ardèche canyon (1575 ha) was classified as a nature reserve in 1980. This reserve encompasses eight towns, with Vallon-Pont d'Arc (118 m asl) upstream. Downstream of Vallon-Pont-d'Arc, the river Ardèche turns eastwards through the reserve to cross a vast plateau of Cretaceous Urgonian limestone, forming a meandering $300 \mathrm{~m}$-deep $29 \mathrm{~km}$-long canyon (Mocochain et al., 2009). All the cliffs along the river Ardèche form this deep limestone canyon. The plateau is covered by coppices and garrigue dominated by holm oak (Q. ilex L.) and box tree (Buxus sempervirens L.).

The study area is submitted to a Mediterranean climate with a pronounced summer drought and autumn rainfall peak. At Orgnac ( $230 \mathrm{~m}$ asl, south of Ardèche canyon), average annual precipitation and mean annual temperatures are respectively $925 \mathrm{~mm}$ and $13.3^{\circ} \mathrm{C}(1970-1998)$.

\subsection{Tree sampling}

The fieldwork was carried out in two steps. First, the trees were surveyed using binoculars to locate potentially very old trees. The most important criterion to find ancient $J$. phoenicea is inaccessibility to humans, which has preserved these rocky cliffs against disturbances such as deforestation for centuries. The second criterion is the presence of very compact rock enabling trees to remain in place. The third criterion in a Mediterranean climate is the absence of slope at the foot of the cliff, which could expose tree to pow-

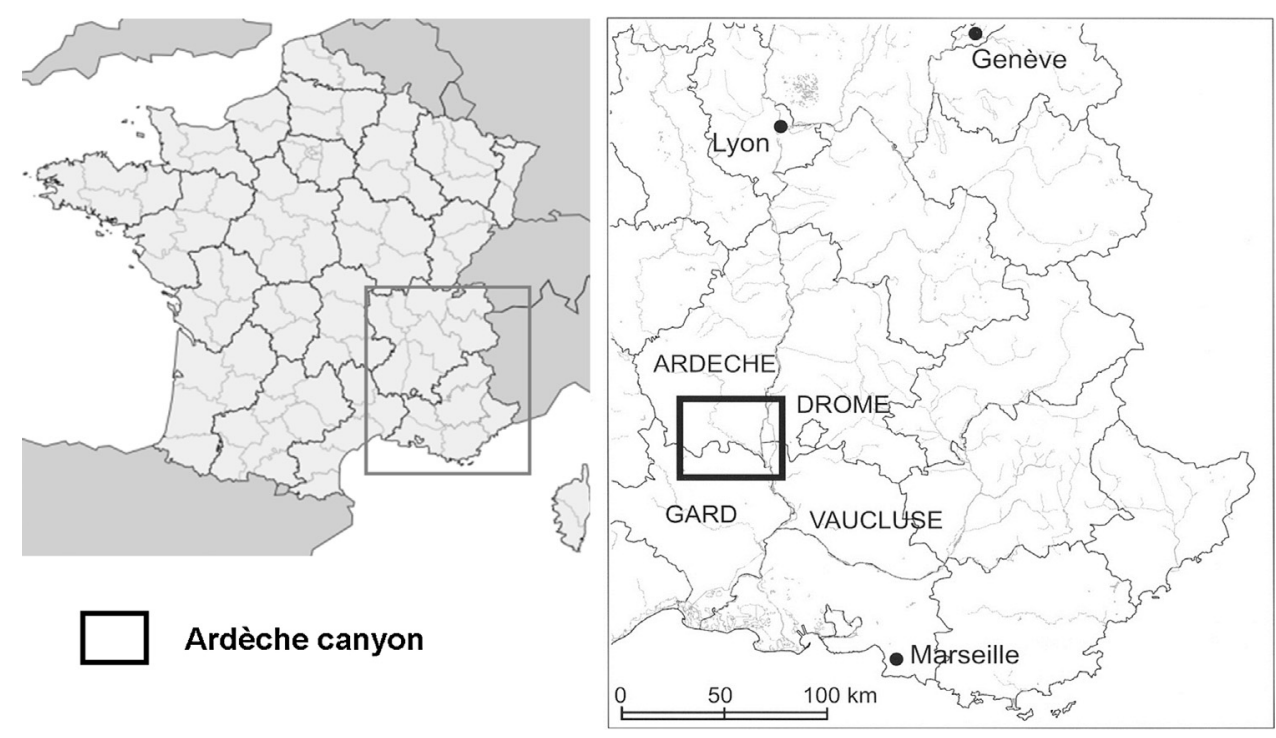

Fig. 1. Location of the Ardèche canyon (France). Courtesy of Christophe Gauchon. 

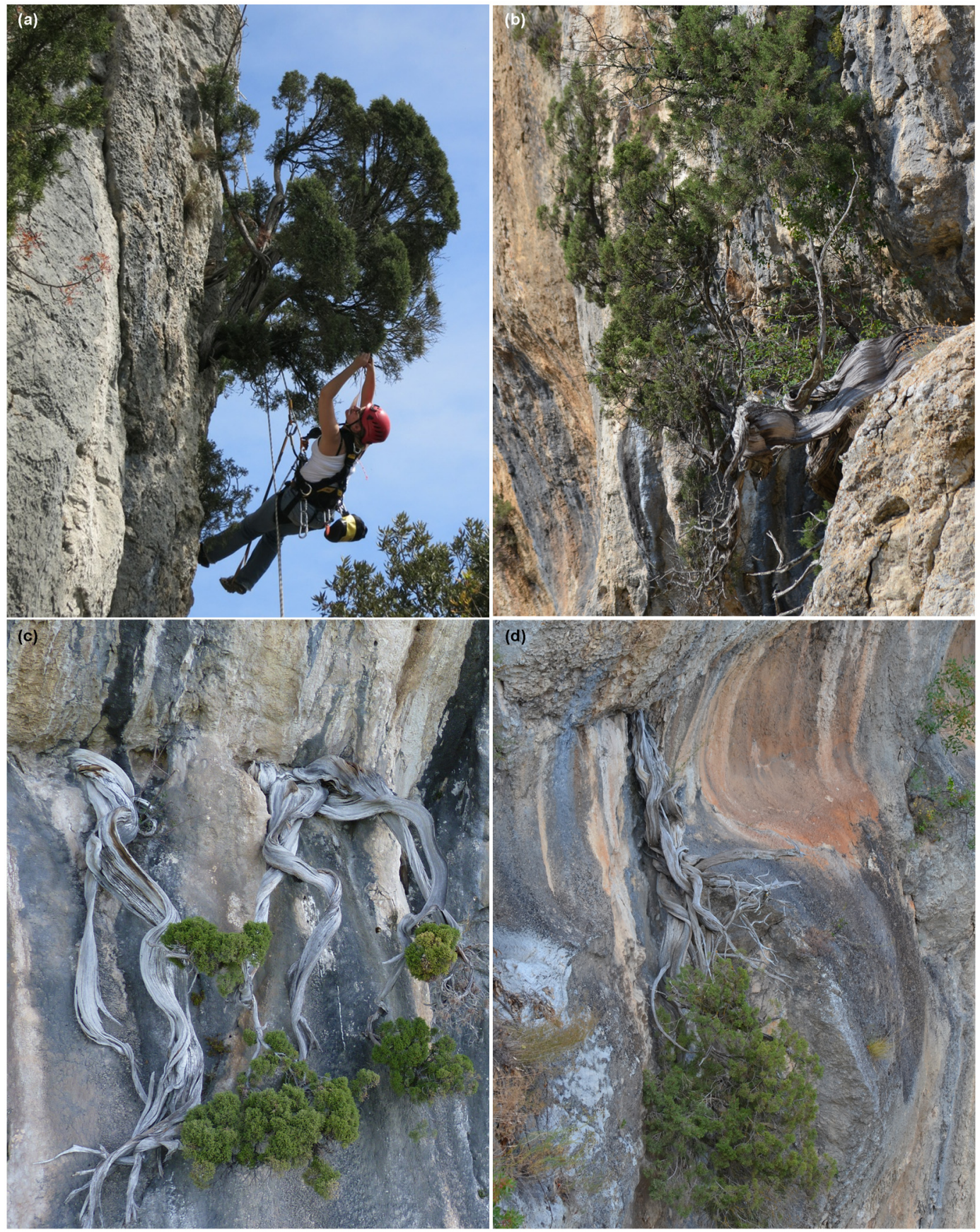

Fig. 2. Tree morphology of Juniperus phoenicea growing on cliffs. (a) erect; (b) horizontal; (c) inverted; (d) inverted with roots growing upwards.

erful hot air convection in the event of severe forest fire (Mandin, 2005). Outside these criteria, Schweingruber (1993) argued that in different species, the oldest trees can be recognized by their appearance, size and shape. Matthes et al. (2008) later confirmed this hypothesis on $T$. occidentalis growing on cliffs by modelling the relationships between age, morphology, growth rate and environment. Mandin (2005) showed that old J. phoenicea have typical morphological characteristics. Aside from a large basal diameter compared with height, old trees can be detected by three criteria: (i) stem is often horizontal or inverted (Kelly et al., 1992) and even sometimes completely inverted with roots growing upwards (Mandin, 2005), (ii) stem and branches are very twisted (Mandin, 2005), and (iii) strip-bark is prominent (Matthes et al., 2008). Indeed, on very old trees, the only functional part of the wood is restricted to a string protected by bark tissue (Larson et al., 1993; Esper, 2000; Mandin, 2005). These criteria were used to identify the trees to be sampled in the second step.

The second step was to collect cross-sections on 52 dead and one living juniper from five sites along the Ardèche canyon, and to core 50 living trees. On the cliffs, dead trunks and branches were sampled by rappelling using specific rock-climbing equipment. Morphological and environmental variables were determined to each tree. Stem disks were collected using a hand-saw. In the lab, the disks were sanded down to a 1200 grit band using a belt sander, then 12 stem disks were selected based on high ring count, ring visibility, wood color and radius length. 


\subsection{Morphological and anatomical description}

Careful observation of individuals in several populations of cliffgrowing J. phoenicea revealed a number of trunk morphologies that we recorded to illustrate the varied tree forms. As the shape of the trunks collected conditioned the shape of the cross-sections, we classified the most frequent tree and cross-section morphologies and described the anatomical features of these sections.

\subsection{Crossdating, radiocarbon dating, and wiggle-match dating method}

First we attempted to crossdate different radii of a single stem and different stems under a binocular microscope to get an accurate estimate of tree age (Stokes and Smiley, 1968; Fritts, 1976). We then applied radiocarbon dating in two ways. First, the pith area of six trees was dated. Second, wiggle-match dating (WMD) (Pearson, 1986) was applied on four disks presenting an appropriate number of rings. One of these disks had never previously been pith- ${ }^{14} \mathrm{C}$ dated so was selected for WMD due to the long ring series it offers. WMD combines tree-ring analysis and radiocarbon dates obtained from multiple tree-ring samples of known relative order over an exact number of years. This sequence of ${ }^{14} \mathrm{C}$ dates can then be fitted to time variations of past atmospheric radiocarbon levels recorded in the radiocarbon calibration curve to yield high-precision dating estimates for a given year in the tree-ring sequence (Pearson, 1986; Ramsey et al., 2001; Bayliss and Tyers, 2004). WMD is usually performed for dating of tree-ring sequences when dendrochronology is impossible (Galimberti et al., 2004). Here we used WMD to test for differences between radiocarbon dates and ring counts. Six to seven 12-year segments of tree-rings were sampled on each of four disks; exact ring counts gave relative positional segment sequence on each slice. We selected 12-year segments for wiggle-matching as most of the samples include periods of extremely narrow rings offering limited samplable material. We thus obtained a series of closely sequentially spaced ${ }^{14} \mathrm{C}$ dates. The AMS date sequences for each sample were wiggle-matched using OxCal 4.2.3 (Ramsey, 2009) and compared against the IntCal13 radiocarbon calibration curve (Reimer et al., 2013). We obtained seven ${ }^{14} \mathrm{C}$ dates on three disks with pith (03AUT5, 02PTT1, 03TEM6) and six ${ }^{14} \mathrm{C}$ dates on a disk without pith (01HUG1b).

\section{Results}

\subsection{Morphological and anatomical description}

$J$. phoenicea growing on cliffs tends to present a small, stunted and distorted gross morphology (Fig. 2a-d). Trunks have variable orientation. Tree morphology can be erect (Fig. 2a), horizontal (Fig. 2b) or inverted (Fig. 2c) and sometimes completely inverted with roots growing upwards (Fig. 2d). Many Phoenician junipers are branched from the bottom and multistemmed. Trunks are often twisted (Fig. 2d). Many individuals apparently show discontinuous cambium function that produces a very irregular trunk contour and asymmetric radial growth of the shoot.

The first rings are often concentric, after which ring geometry often becomes eccentric. The stem cross-sections can be divided into three types of shape: more or less circular or oval (Fig. 3a), slightly to deeply lobed (=star-shaped) (Fig. 3b), and flattened. Among the flattened shapes, some can be unilaterally flattened from the pith, some bilaterally flattened from the pith (Fig. 3c), and others refolded (Fig. 3d). Some stems combine varied geometries, such as flattened then lobed. Given that very complex morphologies were predominant in our sample, we decided to use only stem disks rather than cores where a large number of rings could be lost.
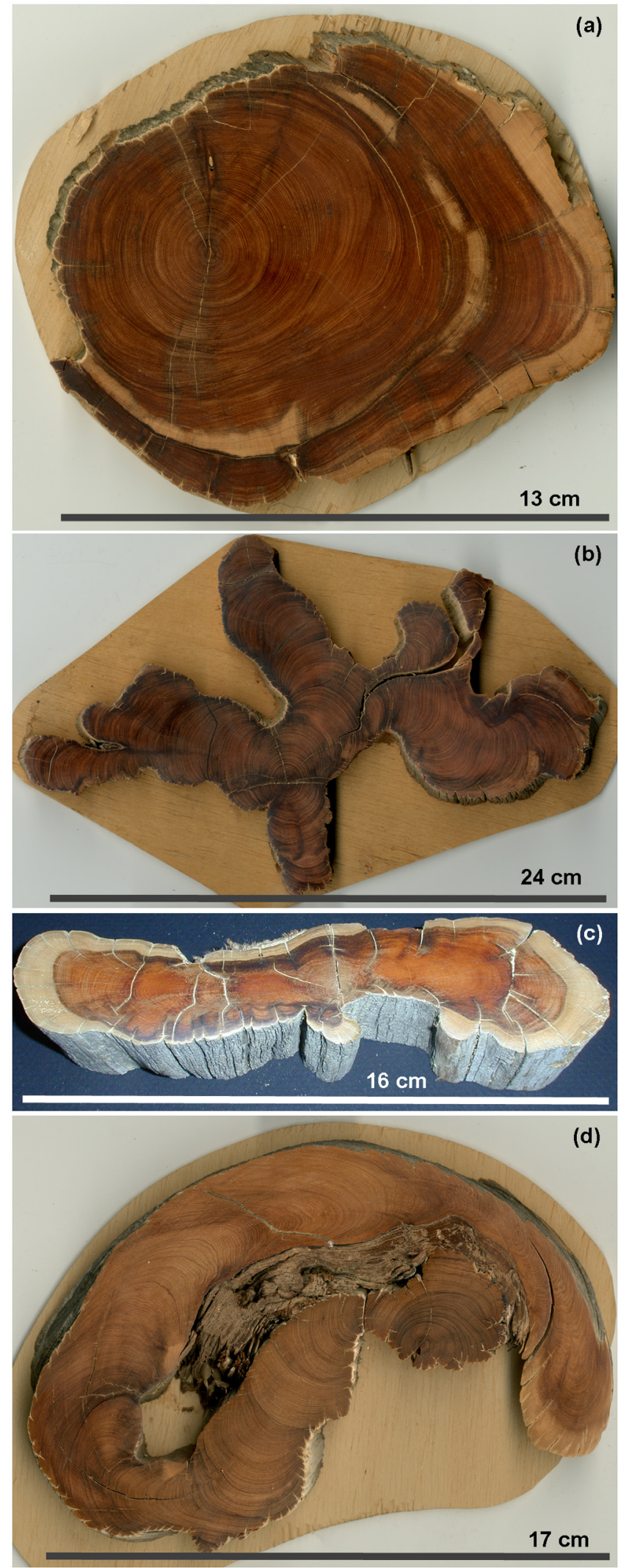

Fig. 3. Stem cross-sections of Juniperus phoenicea growing on cliffs. (a) more or less circular or oval; (b) star-shaped; (c) flattened; (d) refolded. 


\subsection{Radial growth and crossdating}

In terms of secondary growth, in these harsh growing conditions, some trees can get very old. Nevertheless, tree age was simply assessed by counting growth layers. Precise age remains unknown as nothing is known on the seasonality of a growth layer. Indeed, there are many anatomical anomalies. Both false and partially missing rings (=wedging rings) are visible under the microscope (Fig. 4a) to such an extent that there is persistent uncertainty about the periodicity of ring formation, making it very difficult to crossdate by skeleton plot technique. Furthermore, annual radial growth is very low (Fig. 4b) and varies according to radius, some areas are darkened by the presence of secondary metabolites in the wood tissue (Fig. 4c), and intra-annual density fluctuations are frequent (Fig. 4d). The complex morphology of the trunks combined with these many anatomical anomalies impede the fundamental crossdating stage, which is a prerequisite for the determination of an accurate age.

\subsection{Radiocarbon dating}

Given the failure to crossdate, we decided to test the hypothesis that observed growth layers are annual rings by achieving radiocarbon dating in the pith area of five trees. Samples 03TEM6, 02PTT1, 02PTT2, 03AUT4a were collected from dead trees and sample 03AUT5 was from a living tree. The radiocarbon dates span the period 2520-685 BP (Table 1). Radiocarbon dating pointed to ages that diverged widely from the ages assessed by ring counting. Minimal difference between the number of counted rings and the most recent calibrated date was between 1792 years (Tree 03TEM6) and at least 15 years (Tree 03AUT5). For example, Tree 03TEM6 was sampled in 2003, the minimal difference between ring count and calibrated age was calculated as follows: [(year of tree sampling (2003) - (number of counted rings (735)) - (youngest calibrated age $(-524))]=1792$ years. The outer part of this trunk was weathered which may explain that difference. For the other three dead trunks, the minimal difference between ${ }^{14} \mathrm{C}$ age and ring count was relatively low, even though ring counting underestimated the age compared to ${ }^{14} \mathrm{C}$ age. The trunk of the living tree has a ${ }^{14} \mathrm{C}$ age of $1190 \pm 30 \mathrm{BP}$ (calibrated age 730-936 AD) while the number of rings counted is only 1052 .

\subsection{Wiggle-match dating}

WMD was applied on four trees from cliffs of the Ardèche valley with ring counts of 652 (02PTT1) up to 1234 (01HUG1b). The ${ }^{14} \mathrm{C}$ dates obtained for disks 03AUT5, 02PTT1, 01HUG1b spanned 600, 500 and 650 years, respectively. The results are shown in Fig. 5a-d with the fit to the calibration curve provided by the OxCal program. The fit is good although some segments of tree-rings are slightly more scattered than one might expect based on the chi-square values (see Fig. 6a-d). As regards 03TEM6, the overall agreement is poor due to a few plateaux on the calibration curve. For 03AUT5, it appears that the difference between ring count and ${ }^{14} \mathrm{C}$ dates is small for the first six dates but higher for the seventh date. Accordingly, the uncertainty of our counting appears moderate. The gap appears to arise from rings that are totally missing, although such missing rings appear fairly uncommon. For 02PTT1 and 01HUG1b, there were a few outliers due to plateaux in the calibration curve, over 1450-1600, 1750-1800, and 800-900, 1450-1600, respectively.

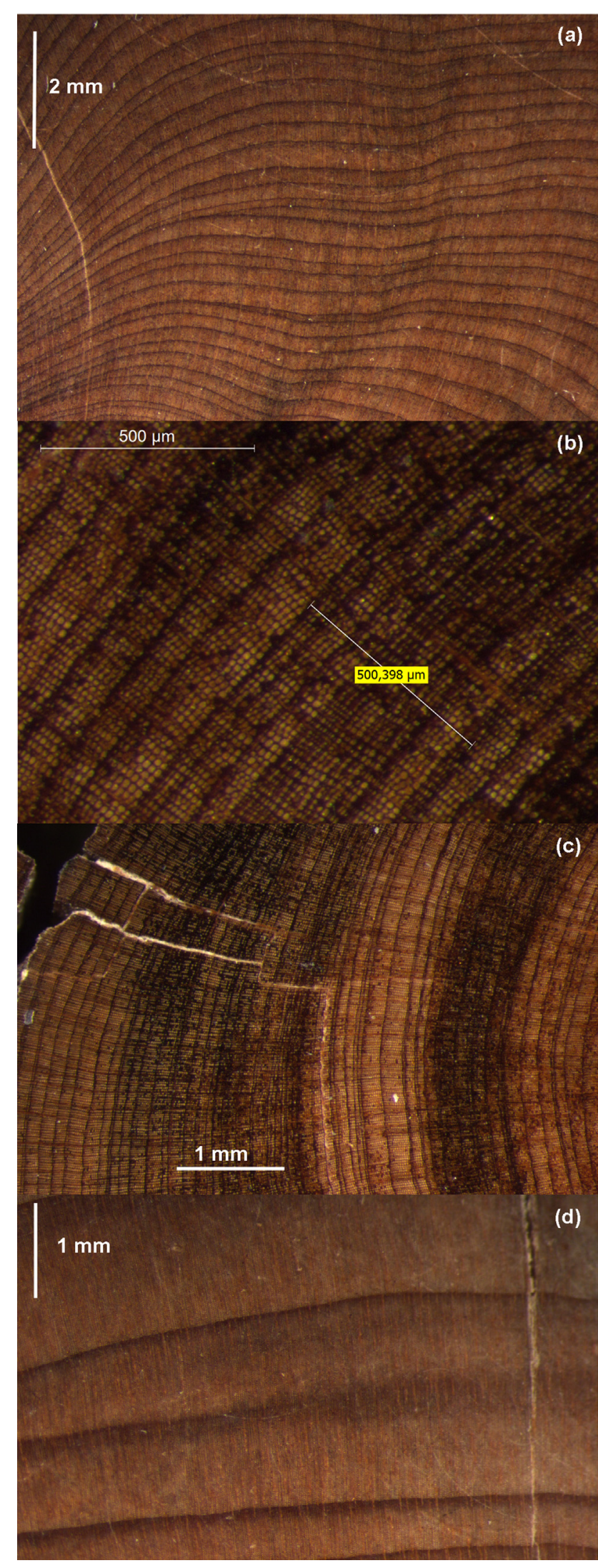

Fig. 4. Anatomical anomalies visible on Juniperus phoenicea growing on cliffs. (a) partially missing rings; (b) extremely narrow rings (13 rings in $500 \mu \mathrm{m}$ ); (c) darkened areas due to secondary metabolites; (d) intra-annual density fluctuations. 
Table 1

Radiocarbon dates done in the pith of five Juniperus phoenicea.

\begin{tabular}{|c|c|c|c|c|c|c|}
\hline No. & Tree & Sampling date & Number of rings & Reference & ${ }^{14} \mathrm{C}$ years $(\mathrm{BP})$ & Calibrated date \\
\hline 1 & 03TEM6 & 2003 & 735 & Ly-4105 (SacA) & $2520 \pm 35$ & $792-524 \mathrm{cal} \mathrm{BC}$ \\
\hline 2 & 02PTT1 & 2002 & 652 & Ly-4103 (SacA) & $835 \pm 30$ & $1159-1262 \mathrm{cal} \mathrm{AI}$ \\
\hline 3 & 02РTT2 & 2002 & 506 & Ly-4104 (SacA) & $685 \pm 30$ & $1273-1385 \mathrm{cal} \mathrm{AI}$ \\
\hline 4 & 03AUT4a & 2003 & 1225 & Ly-4102 (SacA) & $1770 \pm 35$ & $136-376 \mathrm{cal}$ AD \\
\hline 5 & 03AUT5 & 2003 & 1052 & Ly-4101 (SacA) & $1190 \pm 30$ & $730-936 \mathrm{cal} \mathrm{AD}$ \\
\hline
\end{tabular}
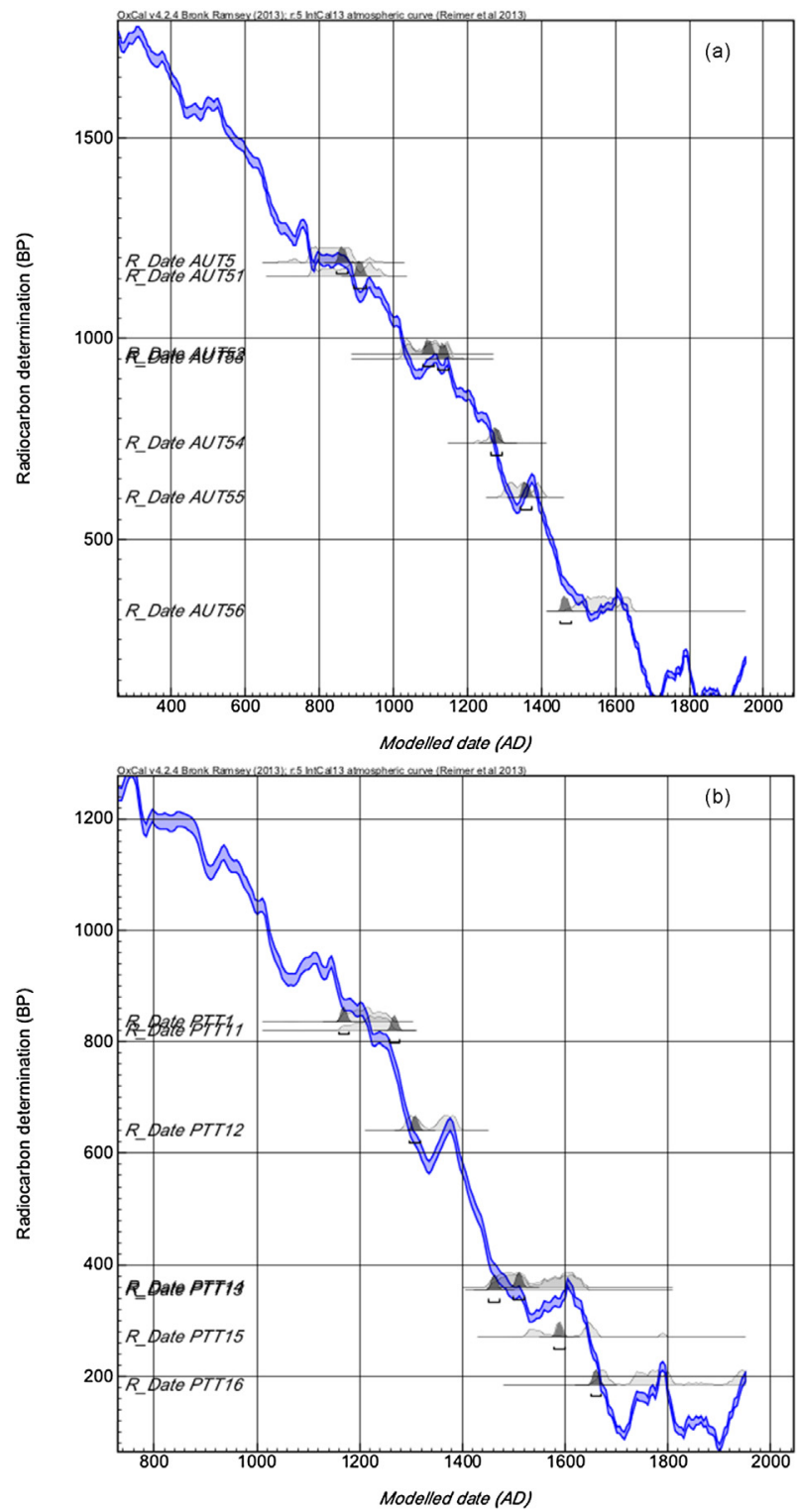
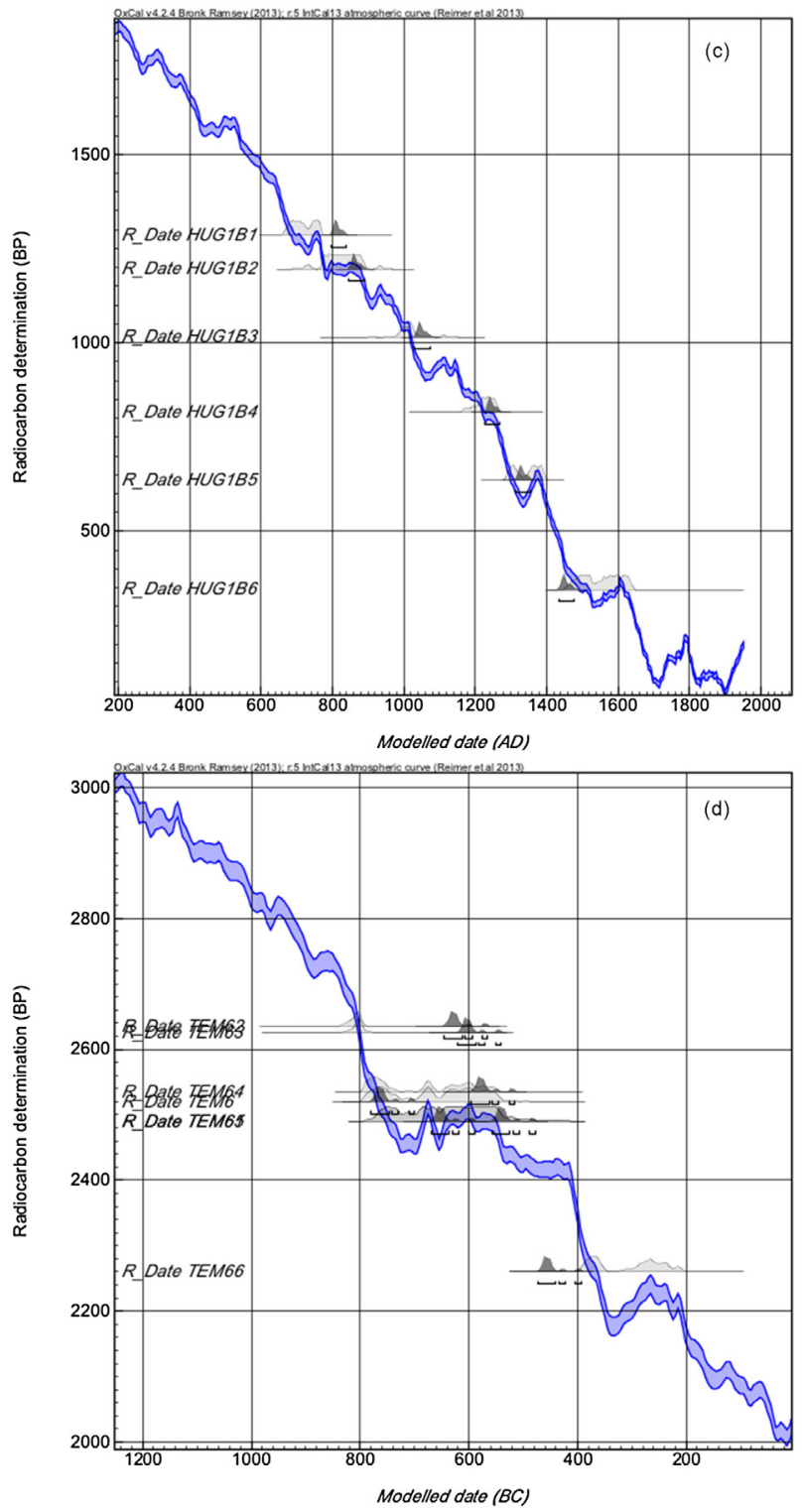

Fig. 5. Wiggle-match plot of sample ((a) 03AUT5, (b) 02PTT1, (c) 01HUG1b, (d) 03TEM6) against INTCAL13 calibration dataset (Reimer et al., 2013).

\section{Discussion}

\subsection{Tree morphology and longevity}

These juniper trees growing on cliffs tend to be small, stunted, and morphologically deformed, with slow growth rates yet great ages. Such trees are found on other very severely environmentallyconstrained sites (Beasley and Klemmedson, 1973; Klötzli, 1991; Swetnam and Brown, 1992; Kelly et al., 1992). For conifers such as Pinus longaeva (Schulman, 1954), Pinus aristata (LaMarche, 1969), Juniperus communis (Ward, 1982), T. occidentalis (Matthes-Sears and Larson, 1995), and angiosperms like Zelkova abelicea (Fazan et al., 2012), growing in adverse and rocky sites, being small does not mean being young. They show extremely slow radial growth and reach a greater longevity.

In the genera Pinus, Cupressus, and Juniperus, some individuals frequently show morphological distortion and asymmetric radial growth of the shoot due to partial cambial mortality (Larson et al., 1993). Trunk morphology distortion, eccentric pith, and star-shaped or other deformed-shape cross-sections seem connected to two phenomena: asymmetric cambial growth and partial cambial mortality. Sectoriality is associated with irregular radial 

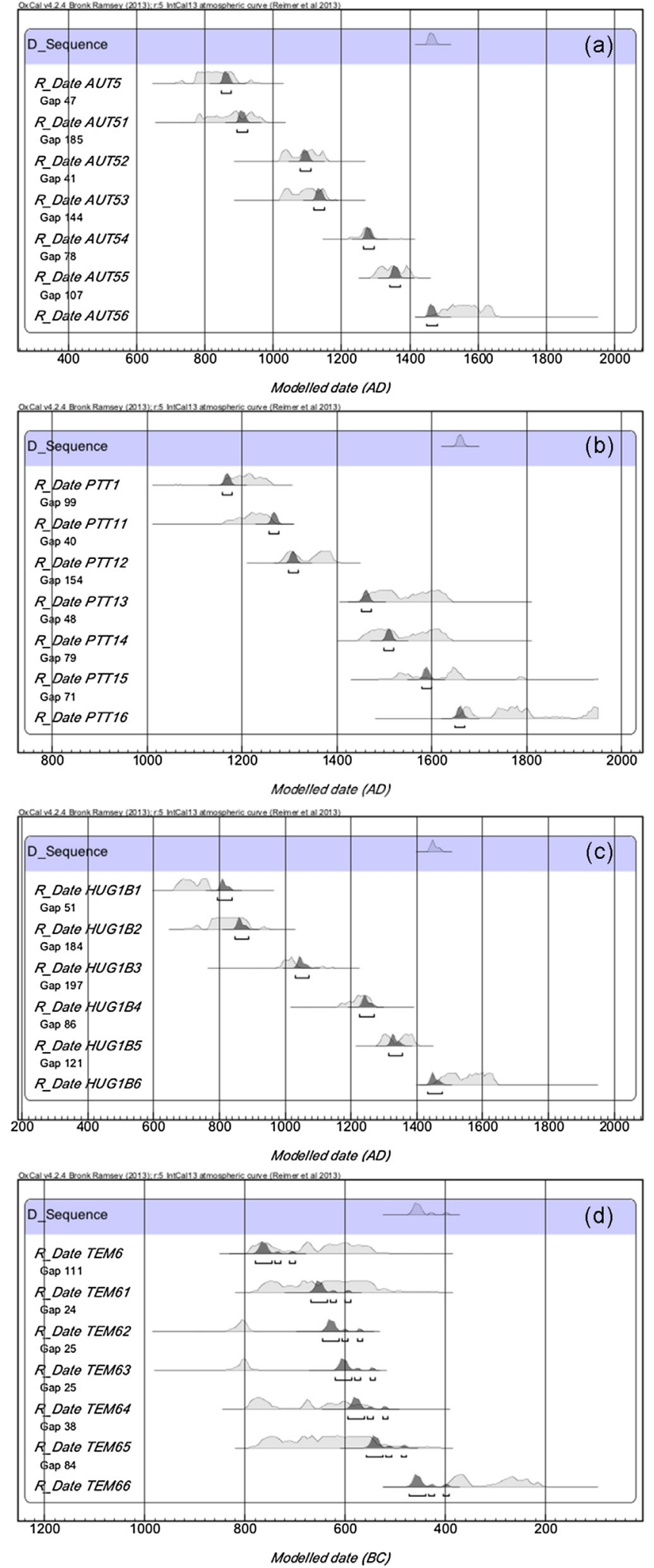

Fig. 6. Composite probability plot of the radiocarbon-dated decades calculated for sample ((a) 03AUT5, (b) 02PTT1, (c) 01HUG1b, (d) 03TEM6) wiggle-matched using OxCal 4.2.3 (Ramsey 2009) and the INTCAL13 calibration dataset (Reimer et al., 2013). Unshaded (hollow) background histograms show total dating probability for each sample in isolation, while black (solid) histograms show the same but for each decade as a part of the wiggle-match. growth (Larson et al., 1994; Mandin, 2006) and allows partial cambial mortality. Cambial activity varies significantly around the circumference of the trunk. Cambial asymmetry is caused by the autonomous stem sub-units that grow differently according to water and nutrient supply at root-system scale (Larson et al., 1994; Cherubini et al., 2003). Cambial mortality, or 'strip-bark' morphology, was first reported by Schulman (1954) in P. longaeva. This process involves the death of the cambium over part of the stem circumference and results in strips of dead exposed wood extending up and down the bole of the tree, alternating with strips of living cambium and bark (Matthes et al., 2002). For Juniperus, the main driver of high cambial mortality seems to be mechanical damage due to rockfall (Esper, 2000). Species that exhibit strip-bark morphology often grow in adverse climatic conditions are long-lived (LaMarche, 1969) with very slow and asymmetric growth (Matthes et al., 2002). In this harsh environment, sectoriality is thought to be a mechanism allowing trees to live to high ages. Mandin (2006) showed that sectoriality could help trees survive in a highly constraining environment and tolerate rockfall and drought-induced damages. Sectoriality could thus keep the impact of potentially deadly events to one part of the tree with few negative effects on the rest of the tree. Furthermore, partial cambial mortality reduces the constraints of gravity by reducing the accumulation of biomass. Bertaudière et al. (2001) postulate that the multi-stemmed type in Juniperus thurifera could offer an adaptive advantage for surviving environments made harsh by topography, soil and climatic conditions. It has been shown in other species that the development of several stems in the same individual, more or less independently, optimized access to water and nutrients (Danin, 1983). For J. phoenicea, these benefits could be added to those provided by sectoriality.

Low radial growth would indicate low investment in primary metabolism, probably to the benefit of secondary metabolism. Cliffs are poor habitats with little competition between widely-spaced trees as there are so few favorable microsites (Matthes and Larson, 2006). In these conditions, trees do not reach a large size and therefore do not have to mobilize a large fraction of their resource budget for primary productivity. Given the small stand density and low competition in both belowground (Matthes-Sears and Larson, 1995) and aboveground organs, fast growth is not necessary. In contrast, in forest ecosystems with no prevailing limiting factor, primary productivity is much higher. For instance, in rainforests, trees have resources to defend themselves. They can achieve great sizes and reach very great ages. In cliffs, the low primary productivity makes resources available for defense mechanisms and reproduction. Loehle $(1988,1996)$ showed that long-lived, slowgrowing trees appear to have effective defense mechanisms against attack from fungi, bacteria and insects. These trees have developed a chemical barrier by allocating a part of their resources to the production of secondary metabolites that are inhibitory or toxic to pathogens (Merrill, 1992). The presence of dark areas in Juniperus wood reflects these compounds. The slow growth rate means that tree-rings have a high latewood percentage, thus a higher content of lignin and a higher wood density that combine to develop a physical barrier (Venet and Keller, 1986) and make the wood resistant to fungal attack. The combination of high wood density and reduced size decreases net mechanical stress (Larson, 2001) and shortens the surface exposed to rockfall, ultimately enabling the trees to survive on the cliffs for several centuries.

\subsection{Anatomical description and crossdating}

The shape of the section leads to strong heterogeneity in radial growth and anomalies in the rings. A high frequency of double rings in the genus Juniperus has been evidenced in J. scopulorum, J. deppeana, J. monosperma, J. osteosperma (Herman, 1956), J. virginiana 
(Kuo and Mac Ginnes, 1973), J. excelsa (Fisher, 1994) and J. thurifera (Bertaudière, 1999). Missing rings were found in J. thurifera (Rozas et al., 2008) and J. excelsa (Couralet et al., 2005; Sass-Klaassen et al., 2008). The complex morphology of the trunks combined with these many anatomical anomalies impede the fundamental crossdating stage, which is a prerequisite for the determination of an accurate age (Stokes and Smiley, 1968). However, in several geographic areas, crossdating has proven successful on some species of Juniperus such as J. thurifera (Bertaudière, 1999), J. excelsa and J. turkestanica (Esper, 2000), and J. procera (Wils et al., 2011). Camarero et al. (2014) found significant relationships between several annually-resolved tree-ring variables and climatic factors during the second half of the 20th century across a network of Iberian $J$. thurifera forests. They showed that higher values of minimum wood density are related to drier spring conditions, particularly in the most xeric sites. As regards J. phoenicea, crossdated trees made it possible to reconstruct annual rainfall back to 1432 in north and central Sinai (Waisel and Liphschitz, 1968). In southern Jordan, at an elevation of $1100-1400 \mathrm{~m}$ asl, a chronology of $J$. phoenicea spans 1600-1995 (Touchan et al., 1999).

\subsection{Radiocarbon dating}

Radiocarbon dating revealed ages that were different from those estimated by ring counts. We can conclude that ring counting underestimates rather than overestimates actual age. For Tree 03TEM6, this minimal difference can be explained by three factors: (i) the alteration of the external part of the trunk by weathering and erosion (wind, water, rockfall), so an unknown number of rings is missing, (ii) the visual ring count underestimates the actual age of the tree due to a high number of completely missing rings following the cessation of cambium functioning in some years, and (iii) the tree staying in place over many centuries after its death (snags). Larson (2001) showed the presence of totally intact coarse woody debris of $T$. occidentalis persisting on cliffs for about 3700 years. The wood of Cupressaceae is very durable and resistant; the molecules responsible for the durability of the wood are tropolones (Haluk and Roussel, 2000) and the chemicals in J. phoenicea are typically beta-Thuyaplicins and Nootkatins (Runeberg, 1960). Ring counts and calibrated age for Tree 03AUT4a show a minimal difference of 402 years for a calibrated age between 136 and 376 AD. Accordingly, the trunk is eroded and there may be relatively many missing rings and/or the tree has remained in place for 400 years at most. Ring counts and calibrated age for Tree 03AUT5 show a minimal difference of at least 15 years for a calibrated age between 730 and $936 \mathrm{AD}$. The tree was alive at the time of sampling, so the difference probably reflects the number of missing rings.

\subsection{Wiggle-match dating}

As regards 03TEM6, the large differences between radiocarbon dates and ring counts are due to the shape of the radiocarbon calibration curve, which features several plateaux. This could have been avoided if we had sampled a living tree, as rings with a high probability of having been formed during a plateau period would have been ruled out.

The fit is good for the other trunks, and the overall agreement with the calibration curve passes a Chi-square test. Minimal difference between radiocarbon dates and ring counts is small. Accordingly, uncertainty over the ring count is low. Clearly, some rings are totally missing, but there are relatively few of them, which means that dendrochronology methods can be applied. This, combined with the high number of old trees in several Ardèche cliff populations (Mathaux et al., in prep.), suggests it will soon be feasible to crossdate juniper trees growing on cliffs and to build up a long chronology from this long-lived species. This connects back to Grissino-Mayer (1993) who stated that J. phoenicea is a species known to crossdate between cores from the same tree as well as between trees from the same site. The time interval between two consecutive radiocarbon dates is rather high, so results could be improved by increasing the resolution of segments in WMD.

\subsection{Outstanding tree ages}

Results obtained in the Ardèche cliffs are consistent with ages evidenced by Larson et al. (2000) in Verdon canyon. J. phoenicea can reach ages of 1500 years, as attested by a juniper found on Manteau Royal cliff, thus providing the longest tree-ring series for the Mediterranean area. In the Mediterranean region, Luterbacher et al. (2012) cites the oldest Morocco cedars (Cedrus atlantica) as aged 1081 years in the Atlas Mountains. J. phoenicea growing on cliffs are probably the oldest trees in France and in the Mediterranean. The literature contains reports of higher ages (1500 years) in oaks and olive trees, but most such reports are only based on assessments (Dupouey, 2010). Indeed, for a number of very old trees (oaks, olive trees), most of the heartwood had collapsed and a lot of rings are lost. The central trunk cavity rules out any attempt to sample any material for radiocarbon dating, so an estimation is proposed based on mean width of the innermost rings and diameter of the trunk, which will yield rather approximate results. In all cases, the papers only report individual very old trees, in contrast to the whole populations of $J$. phoenicea growing on cliffs. The main interest of these junipers is that they have the characteristics of ancient, primary or virgin woodland with a large number of multi-centennial-tomillennial trees and an absence of human disturbance (Larson et al., 1999, 2000). Indeed, the bare rock surfaces of these cliffs have never been used or modified by man. These cliff-face junipers appear to represent the most extensive undisturbed old-growth forest in the Mediterranean area.

The longevity of $J$. phoenicea growing on cliffs prompts questions about the life strategies they have developed. We are currently investigating intra-annual growth study to elucidate the ring formation patterns. In the Mediterranean region, such old trees are uncommon. Another advantage is that intact coarse woody debris is particularly decay-resistant and can remain in place for centuries. For these reasons, such trees can provide very long tree-ring chronologies back to $792-524 \mathrm{cal}$ BC representative of lowland Mediterranean climate (in an altitude range of $50-300 \mathrm{~m}$ asl). Meanwhile, most of the long chronologies built up so far in the Mediterranean involve trees growing at high elevation. Pines (Pinus heldreichii Christ.) in Albania at elevation higher than $1800 \mathrm{~m}$ asl date back to AD 617 (Seim et al., 2010). In southwest Turkey (asl $>1700 \mathrm{~m}$ ), absolute chronologies of Juniperus excelsa span 1017-2001 (Touchan et al., 2007). The Atlas Mountains have yielded long chronologies of $C$. atlantica (1049-2001) at elevations above $2100 \mathrm{~m}$ asl (Esper et al., 2007). In the North Aegean, Griggs et al. (2007) have built up chronologies (Quercus sp.) spanning the years from 1089 to 1989 . The Cyprus mountains ( $1200 \mathrm{~m}$ asl) supplied a 1412-2009 Cedrus brevifolia chronology (Rich et al., 2012). Similar data on J. phoenicea exist for southern Jordan at elevations of 1100-1400 m asl over 1600-1995 (Touchan et al., 1999).

\section{Conclusion}

In ancient trees growing on vertical cliffs, the key question is whether or not the rings are annual. Here we showed that the minimal difference between the radiocarbon dates and ring counts rings is low, proving that missing rings occur but not in any large number. This suggests that accurate annual dating of the tree rings from Ardèche canyon is possible by crossdating, which leads to added confidence in the results of further attempts. 
J. phoenicea growing on cliffs are of high interest in terms of their functioning in past and present cliff ecosystems. On top of providing insights into past cliff population ecology, old junipers are of high value for past climate reconstruction. Crossdating ringwidth series will probably prove a complex challenge but one that could be achieved by using other tree-ring variables such as wood micro-density (Schweingruber et al., 1978; De Micco et al., 2007) or stable isotope content of wood cellulose (Leavitt and Long, 1982; Battipaglia et al., 2010).

In this harsh environment, $J$. phoenicea shows annual treering formation with low and asymmetric radial growth that result in stunted old trees. These trees offer a very promising model for understanding the functioning of trees living in severely environmentally-constrained conditions.

\section{Acknowledgments}

The authors thank the Réserve naturelle des Gorges de l'Ardèche consultative committee for authorizing us to collect samples, and the Syndicat de Gestion des Gorges de l'Ardèche for facilitating the fieldwork. Artemis Committee funded the radiocarbon dating, and the Office de Génie Ecologique provided financial support. We owe particular thanks to the editor and two anonymous reviewers for their critical and valuable comments on our manuscript.

\section{References}

Abdoun, F., Jull, A.J.T., Guibal, F., Thinon, M., 2005. Radial growth of the Sahara's oldest trees: Cupressus dupreziana A. Camus. Trees 19, 661-670.

Battipaglia, G., De Micco, V., Brand, W.A., Linke, P., Aronne, G., Saurer, M., Cherubini, P., 2010. Variations of vessel diameter and $\delta 13 \mathrm{C}$ in false rings of Arbutus unedo L. reflect different environmental conditions. New Phytol. 188, 1099-1112.

Bayliss, A., Tyers, I., 2004. Interpreting radiocarbon dates using evidence from tree rings. Radiocarbon 46, 957-964.

Beasley, R.S., Klemmedson, J.O., 1973. Recognizing site adversity and drought-sensitive trees in stands of bristlecone pine (Pinus longaeva). Econ. Bot. 27, 141-146.

Bertaudière, V., 1999. Dendroécologie du genévrier thurifère (Juniperus thurifera L.) dans la Haute Montagne Méditerranéenne (Haut-Atlas, Maroc) et dans une station xérothermique des Pyrénées Centrales. Université Paul Sabatier, Toulouse.

Bertaudière, V., Montès, N., Badri, W., Gauquelin, T., 2001. La structure multicaule du genévrier thurifère: avantage adaptatif à un environnement sévère? Comptes Rendus de l'Acad. des Sci.-Ser. III- Sci. de laVie 324, 627-634.

Blondel, J., Aronson, J., 1999. Biology and Wildlife of the Mediterranean Region. Oxford University Press, Oxford.

Camarero, J.J., Rozas, V., Olano, J.M., 2014. Minimum wood density of Juniperus thurifera is a robust proxy of spring water availability in a continental Mediterranean climate. J. Biogeogr. 41, 1105-1114.

Campelo, F., Gutierrez, E., Ribas, M., Nabais, C., Freitas, H., 2007. Relationships between climate and double rings in Quercus ilex from northeast Spain. Can. J. For. Res. 37, 1915-1923.

Cherubini, P., Gartner, B.L., Tognetti, R., Braker, O.U., Schoch, W., Innes, J.L., 2003. Identification, measurement and interpretation of tree rings in woody species from Mediterranean climates. Biol. Rev. 78, 119-148.

Couralet, C., Sass-Klaassen, U., Sterck, F., Bekele, T., Zuidema, P.A., 2005. Combining dendrochronology and matrix modelling in demographic studies: an evaluation for Juniperus procera in Ethiopia. For. Ecol. Manag. 216, 317-330.

Danin, A., 1983. Desert Vegetation of Israel and Sinai. Cana Publishing House, Jerusalem.

De Micco, V., Saurer, M., Aronne, G., Tognetti, R., Cherubini, P., 2007. Variations of wood anatomy and $\delta 13 \mathrm{C}$ within-tree rings of coastal Pinus pinaster showing intra-annual density fluctuations. IAWA J. 28, 61-74.

Dupouey, J.L., 2010. Le plus vieil arbre. Revue Forestière Française 62, 671-680.

Dzialuk, A., Mazur, M., Boratynska, K., Montserrat, J.M., Romo, A., Boratynski, A., 2011. Population genetic structure of Juniperus phoenicea (Cupressaceae) in the western Mediterranean Basin: gradient of diversity on a broad geographical scale. Ann. For. Sci. 68, 1341-1350

Esper, J., 2000. Long-term tree-ring variations in Juniperus at the upper timber-line in the Karakorum (Pakistan). Holocene 10, 253-260.

Esper, J., Frank, D., Buntgen, U., Verstege, A., Luterbacher, J., Xoplaki, E., 2007. Long-term drought severity variations in Morocco. Geophys. Res. Lett. 34.

Farjon, A., 2005. A Monograph of Cupressaceae and Sciadopitys. Royal Botanic Gardens, Kew.

Fazan, L., Stoffel, M., Frey, D.J., Pirintsos, S., Kozlowski, G., 2012. Small does not mean young: age estimation of severely browsed trees in anthropogenic Mediterranean landscapes. Biol. Conserv. 153, 97-100.
Fisher, M., 1994. Is it possible to construct a tree-ring chronology for Juniperus excelsa (Bieb.) subsp. polycarpos (K. Koch), Takhtajan from the northern mountains of Oman. Dendrochronologia 12, 119-127.

Fritts, H.C., 1976. Tree Rings and Climate. Academic press, London.

Galimberti, M., Ramsey, C.B., Manning, S.W., 2004. Wiggle-match dating of tree-ring sequences. Radiocarbon 46, 917-924.

Garraud, L., 2003. Flore de la Drôme: atlas écologique et floristique. Conservatoire Botanique National Alpin de Gap-Charance, Gap.

Griggs, C., DeGaetano, A., Kuniholm, P., Newton, M., 2007. A regional high-frequency reconstruction of May-June precipitation in the north Aegean from oak tree rings, AD 1089-1989. Int. J. Climatol. 27, 1075-1089.

Grissino-Mayer, H.D., 1993. An updated list of species used in tree-ring research. Tree Ring Bull. 53, 17-43.

Haluk, J.P., Roussel, C., 2000. Characterization and origin of tropolones responsible for the cupressales natural durability: potential application to wood preservation. Ann. For. Sci. 57, 819-829.

Herman, F.R., 1956. Growth and phenological observations of Arizona junipers. Ecology 37, 193-195.

Kelly, P.E., Cook, E.R., Larson, D.W., 1992. Constrained growth, cambial mortality, and dendrochronology of ancient Thuja occidentalis on cliffs of the Niagara Escarpment: an eastern version of bristlecone pine? Int. J. Plant Sci. 153, 117-127.

Kelly, P.E., Cook, E.R., Larson, D.W., 1994. A 1397-year tree-ring chronology of Thuja occidentalis from cliff faces of the Niagara Escarpment, Southern Ontario, Canada. Can. J. For. Res. 24, 1049-1057.

Klötzli, F.A., 1991. In: Esser, G., Overdieck, D. (Eds.), Niches of Longevity and Stress, Modern Ecology. Elsevier, Amsterdam, pp. 97-110.

Kuo, M., Mac Ginnes, E.A., 1973. Variations of anatomical structure of false rings in eastern redcedar. Wood Sci. 5, 205-210.

LaMarche, V.C., 1969. Environment in relation to age of Bristlecone pine. Ecology $50,53-59$.

Larson, D.W., 2001. The paradox of great longevity in a short-lived tree species Exp. Gerontol. 36, 651-673.

Larson, D.W., Doubt, J., Matthes-Sears, U., 1994. Radially sectored hydraulic pathways in the xylem of Thuja occidentalis as revealed by the use of dyes. Int. J. Plant Sci. 155, 569-582.

Larson, D.W., Matthes, U., Gerrath, J.A., Gerrath, J.M., Nekola, J.C., Walker, G.L., Porembski, S., Charlton, A., Larson, N.W.K., 1999. Ancient stunted trees on cliffs. Nature 398, 382-383.

Larson, D.W., Matthes, U., Gerrath, J.A., Larson, N.W.K., Gerrath, J.M., Nekola, J.C., Walker, G.L., Porembski, S., Charlton, A., 2000. Evidence for the widespread occurrence of ancient forests on cliffs. J. Biogeogr. 27, 319-331.

Larson, D.W., Matthes-Sears, U., Kelly, P.E., 1993. Cambial dieback and partial shoot mortality in cliff-face Thuja occidentalis-evidence for sectored radial architecture. Int. J. Plant Sci. 154, 496-505.

Leavitt, S.W., Long, A., 1982. Stable carbon isotopes as a potential supplementa tool in dendrochronology. Tree Ring Bull. 42, 49-55.

Lemoine, C., 1966. Les bois des Juniperus Essai. d'anatomie écologique de quelques espèces. Bot. Rhedonica 2, 37-86.

Loehle, C., 1988. Tree life-history strategies-the role of defenses. Can. J. For. Res. $18,209-222$.

Loehle, C., 1996. Optimal defensive investments in plants. Oikos 75, 299-302.

Luterbacher, J., García-Herrera, R., Akcer-On, S., Allan, R., Alvarez-Castro, M.-C. Benito, G., Booth, J., Büntgen, U., Cagatay, N., Colombaroli, D., Davis, B., Esper, J., Felis, T., Fleitmann, D., Frank, D., Gallego, D., Garcia-Bustamante, E., Glaser, R., Gonzalez-Rouco, F.J., Goosse, H., Kiefer, T., Macklin, M.G., Manning, S.W., Montagna, P., Newman, L., Power, M.J., Rath, V., Ribera, P., Riemann, D., Roberts, N., Sicre, M.-A., Silenzi, S., Tinner, W., Tzedakis, P.C., Valero-Garcés, B., van der Schrier, G., Vannière, B., Vogt, S., Wanner, H., Werner, J.P., Willett, G., Williams, M.H., Xoplaki, E., Zerefos, C.S., Zorita, E., 2012. A Review of 2000 Years of Paleoclimatic Evidence in the Mediterranean. In: Lionello, P. (Ed.), The Climate of the Mediterranean Region: From the Past to the Future. Elsevier, Oxford, pp. 87-185.

Mandin, J.P., 2005. Découverte de très vieux genévriers de Phénicie (Juniperus phoenicea L.) dans les gorges de l'Ardèche (France). J. Bot. 29, 53-62.

Mandin, J.P., 2006. Morphologie des très vieux genévriers de Phénicie (Juniperus phoenicea L.) en parois rocheuses (gorges de l'Ardèche, France). III Coloquio Internacional sobre los sabinares y enebrales (Género Juniper us): Ecologia y Gestion Forestal Sostenible, Soria (Espagne), 24-26 May 2006, vol. 1, 303-310.

Matthes, U., Kelly, P.E., Larson, D.W., 2008. Predicting the age of ancient Thuja occidentalis on cliffs. Can. J. For. Res. 38, 2923-2931.

Matthes, U., Kelly, P.E., Ryan, C.E., Larson, D.W., 2002. The formation and possible ecological function of stem strips in Thuja occidentalis. Int. J. Plant Sci. 163, 949-958.

Matthes, U., Larson, D.W., 2006. Microsite and climatic controls of tree population dynamics: an 18-year study on cliffs. J. Ecol. 94, 402-414.

Matthes-Sears, U., Larson, D.W., 1995. Rooting characteristics of trees in rock: a study of Thuja occidentalis on cliff faces. Int. J. Plant Sci. 156, 679-686.

Merrill, W., 1992. Mechanisms of resistance to fungi in woody plants: a historical perspective. In: Blanchette, R.A., Biggs, A.R. (Eds.), Defense Mechanisms of Woody Plants Against Fungi. Springer, Berlin, Heidelberg, pp. 1-12.

Mocochain, L., Audra, P., Clauzon, G., Bellier, O., Bigot, J.Y., Parize, O., Monteil, P., 2009. The effect of river dynamics induced by the Messinian Salinity Crisis on karst landscape and caves: example of the lower Ardeche river (mid Rhone valley). Geomorphology 106, 46-61. 
Pearson, G.W., 1986. Precise calendrical dating of known growth-period samples using a curve fitting technique. Radiocarbon 28, 292-299.

Quézel, P., Médail, F., 2003. Ecologie et biogéographie des forêts du bassin méditerranéen. Elsevier, Paris.

Quézel, P., Pesson, P., 1980. Biogéographie et écologie des conifères sur le pourtour méditerranéen. In: Actualités d'écologie forestière. Gauthier-Villars, Paris, pp. 205-255.

Rameau, J.C., Mansion, D., Dumé, G., Gauberville, C., 2008. Flore forestière française: Région Méditerranéenne. Institut pour le Développement Forestier, Paris.

Ramsey, B.C., 2009. Bayesian analysis of radiocarbon dates. Radiocarbon 51, 337-360.

Ramsey, B.C., van der Plicht, J., Weninger, B., 2001. 'Wiggle matching' radiocarbon dates. Radiocarbon 43, 381-389.

Reimer, P.J., Bard, E., Bayliss, A., Beck, J.W., Blackwell, P.G., Ramsey, C.B., Buck, C.E. Cheng, H., Edwards, R.L., Friedrich, M., Grootes, P.M., Guilderson, T.P., Haflidason, H., Hajdas, I., Hatte, C., Heaton, T.J., Hoffmann, D.L., Hogg, A.G., Hughen, K.A., Kaiser, K.F., Kromer, B., Manning, S.W., Niu, M., Reimer, R.W., Richards, D.A., Scott, E.M., Southon, J.R., Staff, R.A., Turney, C.S.M., van der Plicht, J., 2013. IntCal13 and marine13 radiocarbon age calibration curves 0-50,000 years cal BP. Radiocarbon 55, 1869-1887.

Rich, S., Manning, S.W., Degryse, P., Vanhaecke, F., Van Lerberghe, K., 2012. Strontium isotopic and tree-ring signatures of Cedrus brevifolia in Cyprus. J. Anal. At. Spectr. 27, 796-806.

Rozas, V., Olano, J.M., DeSoto, L., Bartolome, D., 2008. Large-scale structural variation and long-term growth dynamics of Juniperus thurifera trees in a managed woodland in Soria, central Spain. Ann. For. Sci. 65.

Runeberg, J., 1960. The chemistry of the natural order cupressales: 31 . heartwood constituents of Juniperus phoenicea L. Acta Chem. Scand. 14, 1995-1998.

Sass-Klaassen, U., Leuschner, H.H., Buerkert, A., Helle, G., 2008. Tree-ring analysis of Juniperus excelsa from the northern Oman mountains. Tree Rings Arch. Climatol. Ecol. 6, 99-108.
Schulman, E., 1954. Longevity under adversity in conifers. Science 119, 396-399. Schweingruber, F.H., 1993. Trees and Wood in Dendrochronology: Morphological, Anatomical and Tree-Ring Analytical Characteristics of Trees Frequently Used in Dendrochronology. Springer-Verlag, Berlin.

Schweingruber, F.H., Fritts, H.C., Bräker, O.U., Drew, L.G., Schär, E., 1978. The X-ray technique as applied to dendroclimatology. Tree Ring Bull. 38, 61-91.

Seim, A., Treydte, K., Büntgen, U., Esper, J., Fonti, P., Haska, H., Herzig, F., Tegel, W., Faust, D., 2010. Exploring the potential of Pinus heldreichii CHRIST for long-term climate reconstruction in Albania. Tree Rings Arch. Climatol. Ecol. 8, 75-82.

Stokes, M.A., Smiley, T.L., 1968. An Introduction to Tree-Ring Dating. University of Chicago Press, Chicago.

Swetnam, T.W., Brown, P.M., 1992. Oldest known conifers in the Southwestern United States: temporal and spatial patterns of maximum age, Old Growth Forests in the Southwest and Rocky Mountain Regions. USDA Forest Service General Technical Report RM-213, pp. 24-38.

Touchan, R., Akkemik, U., Hughes, M.K., Erkan, N., 2007. May-June precipitation reconstruction of Southwestern Anatolia, Turkey during the last 900 years from tree rings. Quat. Res. 68, 196-202.

Touchan, R., Meko, D., Hughes, M.K., 1999. A 396-year reconstruction of precipitation in southern Jordan. J. Am. Water Resour. Assoc. 35, 49-59.

Venet, J., Keller, R., 1986. Identification et classement des bois français. 2ème édition revue par R. Kell er, École nationale du génie rural, des eaux et des forêts, Nancy.

Waisel, Y., Liphschitz, N., 1968. Dendrochronological studies in Israel II. Juniper us phoenicea of north and central Sinai. La Yaaran 18,67-69.

Ward, L.K., 1982. The conservation of Juniper-longevity and old-age. J. Appl. Ecol. 19, 917-928.

Wils, T.H.G., Robertson, I., Eshetu, Z., Touchan, R., Sass-Klaassen, U., Koprowski, M. 2011. Crossdating Juniperus procera from North Gondar, Ethiopia. Trees-Struc. Funct. 25, 71-82. 